\title{
Factors to consider in Micronesian food-based interventions: a case study of preventing vitamin A deficiency
}

\author{
L Englberger $^{1,2, *}$, GC Marks ${ }^{1}$ and MH Fitzgerald ${ }^{3}$ \\ ${ }^{1}$ Australian Centre for International and Tropical Health and Nutrition, School of Population Health, University of \\ Queensland, Brisbane, Australia: ${ }^{2}$ Correspondence address: PO Box 2299, Kolonia, Pohnpei, 96941 Federated \\ States of Micronesia: ${ }^{3}$ School of Occupation and Leisure Studies, University of Sydney, Sydney, Australia
}

Submitted 24 June 2003: Accepted 11 September 2003

\begin{abstract}
Background: Many factors need to be considered in a food-based intervention. Vitamin A deficiency and chronic diseases, such as diabetes, heart disease and cancer, have become serious problems in the Federated States of Micronesia (FSM) following the decreased production and consumption of locally grown foods. However, agricultural and social conditions are still favourable for local food production.

Aim: To identify key factors to consider in a Micronesian food-based intervention focusing on increased production and consumption of four major Micronesian staple foods: banana, breadfruit, giant swamp taro and pandanus.

Methods: Ethnographic methods including key informant interviews and a literature review.

Results: Pacific and Micronesian values, concepts of food and disease, and food classifications differ sharply from Western concepts. There are few FSM professionals with nutrition expertise. Traditional foods and food cultivars vary in nutrient content, consumption level, cost, availability, status, convenience in growing, storing and cooking, and organoleptic factors.

Conclusions: A systematic consideration of the factors that relate to a food-based intervention is critical to its success. The evaluation of which food and cultivar of that food that might be most effectively promoted is also critical. Regional differences, for example FSM inter-island differences between the staple foods and cultivars, must be considered carefully. The evaluation framework presented here may be relevant to Pacific Island and other countries with similar foods where food-based interventions are being planned. An ethnographic approach was found to be essential in understanding the cultural context and in data collection and analysis.
\end{abstract}

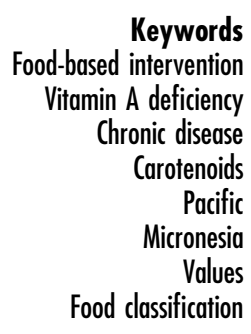

Food-based interventions are promoted as an essential part of long-term strategies to alleviate micronutrient deficiencies. In order for a food-based intervention to be successful in achieving dietary improvement, many factors need to be considered. This paper discusses factors and approaches important for a food-based intervention in the Federated States of Micronesia (FSM) focused on preventing vitamin A deficiency (VAD) and chronic diseases, including diabetes, heart disease and cancer, through increased consumption of provitamin A and total carotenoids. There are serious problems of $\mathrm{VAD}^{1-4}$ and chronic diseases $^{5-8}$ in FSM. Consumption of foods rich in provitamin A carotenoids may alleviate $\mathrm{VAD}^{9}$, and epidemiological evidence suggests that carotenoid-rich foods may protect against these chronic diseases ${ }^{10-13}$.

Nutrition-related chronic disorders have developed since the 1960s, following a decrease in production and consumption of local foods, increased consumption of rice, sugar, wheat flour, fatty meats and other refined foods, and changes in lifestyle ${ }^{14}$. Inconsistent internal and external government policies, food aid programmes, lifestyle changes, the change from a subsistence to a market economy, and the convenience, cost and prestige of imported foods have contributed to the dietary shift from localt to imported foods ${ }^{6,15-17}$. However, agricultural and other social conditions are still favourable for local food production.

Cultivars of Micronesian staple foods (banana, breadfruit, giant swamp taro and pandanus) have been found to contain high amounts of provitamin $\mathrm{A}$ and total carotenoids $^{18-20}$. Yellow or orange coloration is an indicator of carotenoid content ${ }^{21}$ and has been demonstrated to be an indicator of carotenoid content for certain Micronesian cultivars ${ }^{18-20}$. Pumpkin and sweet potato,

†Local foods in this paper refer to foods that are locally grown, harvested, hunted or gathered from the land or sea. 
which are eaten in some parts of Micronesia and for which there are vitamin A (VA)-rich cultivars, are generally not well liked or commonly eaten in the region where this study took place ${ }^{22}$. Thus, they were not included among the foods investigated.

This paper examines factors that may influence the success of an FSM food-based intervention aiming to increase the production and consumption of foods that could alleviate VAD. While the basic work was done with respect to VAD, the same approach could be applied to food-based strategies to improve the consumption of a variety of nutrients in this and other parts of the world.

\section{Methods}

Data were collected as part of an overall study to identify VA-rich foods that could be promoted to alleviate VAD in FSM. The study was conducted in Kosrae, a single-island mountainous state, and Pohnpei, the mountainous island where the FSM national government is based. In Kosrae there is primarily one ethnic group (Kosraean). In Pohnpei, most people are Pohnpeian, but there are also many people from other FSM islands who have distinct languages and cultures. An ethnographic approach was taken using a literature review, key informant interviews, focus group discussions, pile sorting and participant observation, following methods described in guidelines developed for studies of this type $\mathrm{e}^{23-25}$.

The multidisciplinary literature review included data from published and unpublished papers, selectively targeting relevant areas, including the identification of cultivar lists for the main staple foods and characteristics of those cultivars. The key informants included people from different ages (17 to 86 years), occupations (including students, farmers, housewives, non-governmental and governmental officers), islands and areas of the islands, selected purposively for information-rich cases ${ }^{26}$. In total, 91 male and 55 female informants were formally interviewed, all living in Kosrae and Pohnpei (some originating from Chuuk, Yap and Pohnpei outer islands). The interviews were semi-structured, following an interview guide with questions about the foods, coloration and factors relating to production, consumption and acceptability. As informants were interviewed other people often became interested in the discussion, joined in and added information, resulting in an informal focus group discussion. What happened in these situations replicates common behaviour in open, social communities like those in Kosrae and Pohnpei, and provided in-depth information that might otherwise not have been obtained. For pile sorting, illustrated cards for 30 foods (locally grown and imported) were prepared; participants were asked to group these however they liked (non-directed pile sorting) and according to acceptability by taste, convenience and cost (directed pile sorting) ${ }^{24}$. The aim was to gain information on acceptability of the foods that might be most easily promoted. Research approval was obtained from the University of Queensland Medical Research Ethics Committee and FSM National Health Research Committee. The data were analysed by thematic analysis and triangulation of multiple methods, and data sources were used to strengthen the validity and accuracy of information $^{26}$. For confirming data analysis results, the findings of the analysis were fed back to the participants who gave the information.

\section{Results and discussion}

The approach to data collection yielded a rich and complex body of data, which were considered by several themes. Lessons learned from successful nutrition programmes and frameworks for planning interventions involving behavioural change emphasise the importance of understanding the population and context ${ }^{27-30}$. Key themes are Micronesian values and their implications, food classifications, and health care and community expertise. In addition, programme factors (including programme design and implementation) are discussed.

\section{Micronesian values and their implications}

Other authors have noted that understanding Pacific and Western values is essential in planning nutrition programmes in the Pacific ${ }^{31,32}$ and other communities. The 'Pacific Way' is described as an 'inherent brotherhood born of similarity of life and living values', in which 'the extended family and communalism are fundamental ${ }^{33}$. Rody ${ }^{34}$, among others, describes Western values as task-oriented, with Micronesian values more person-oriented (Table 1).

The concept of food for Pacific people differs from the concept of food held by many Westerners ${ }^{32}$. For many Westerners the discourse on food and nutrition tends to focus on physical factors and meanings and, thus, nutrition educators often stress only the biological aspects. However, for Pacific people, food is often seen as a means of expressing social relationships in terms of the social context. For example, funerals are large-scale events in $\mathrm{FSM}^{15}$ requiring food donations for maintaining social relationships. One report estimated that $30 \%$ of the average annual income is devoted to funerals ${ }^{35}$; an informant said that $10-15 \%$ was a more likely amount today. This person, like other informants, stressed the burden involved and said that often food is wasted or given to the pigs; but, nevertheless, custom demanded such donations. The traditional concept of sharing and ownership in the Pacific, including Micronesia, is different from Western concepts ${ }^{32}$ (Table 1). In addition, for Pacific Islanders, health is more a group concept than an individual one. For example, mothers are fed large amounts of food and are supported emotionally for their, the child's and the whole family's well-being ${ }^{36}$.

Finau $^{33}$, like others, states that there is a need to reorient the health systems in the Pacific to a more socioculturally 
Table 1 General features of Pacific life and living concepts

\begin{tabular}{|c|c|}
\hline Pacifican & Euro-American \\
\hline Nature will provide for us in time & $\begin{array}{l}\text { We must change our world, control nature and make } \\
\text { it work for man }\end{array}$ \\
\hline What will be will be. Man's life is controlled by destiny & We create our own future by what we do \\
\hline $\begin{array}{l}\text { There's no use rushing away from what I'm doing now. } \\
\text { There's always plenty of time }\end{array}$ & I have to hurry and meet somebody new. See you later \\
\hline Worry about tomorrow when tomorrow comes & Save for the future \\
\hline $\begin{array}{l}\text { Work a little, rest a little. Whatever you do try to keep } \\
\text { other people happy }\end{array}$ & If I work hard enough, someday I'll make it to the top \\
\hline What I have is yours. What you have is mine & What's mine belongs to me \\
\hline $\begin{array}{l}\text { The wise man is one who knows his place in the world, } \\
\text { respects authority and does what he is supposed to do }\end{array}$ & $\begin{array}{l}\text { The sensible man is one who strikes out on his own, } \\
\text { learns to do things for himself and makes his own } \\
\text { decisions }\end{array}$ \\
\hline $\begin{array}{l}\text { The feelings of others are more important than } \\
\text { an honest answer }\end{array}$ & Always tell the truth, no matter how it hurts \\
\hline My life belongs to the family and God & I am a god \\
\hline
\end{tabular}

Source: Pacific Daily News (1989), cited in Finau ${ }^{33}$.

appropriate model. His psychosociocultural or ecological model may offer insight for those planning a food-based intervention to effect health improvement (Fig. 1). It shows that a person's health status is closely linked with social relationships, which is a strong belief in the Pacific.

An attitude that prevails in FSM is that Western systems are better ${ }^{17,37,38}$. FSM informants said that local people often want to copy Western practices. Pollock ${ }^{32}$ notes that some Western ideas, including eating only at mealtimes, regular meals, the concept of vegetables as foods for humans and the Three Food Groups guidelines, have been used widely throughout the Pacific ${ }^{39}$, but these vary from Pacific Islanders' concepts on eating. Study informants stressed that fruits are not eaten as a part of meals in FSM, but as snacks. Green leafy vegetables are considered by many as food only for animals ${ }^{40,41}$. Pollock ${ }^{32}$ referred to the slogan 'Eat Local Foods', which has been encouraged in many Pacific Island countries ${ }^{42}$ for its health, economic and cultural benefits. However, eating local foods strongly contradicts years of conflicting messages from European

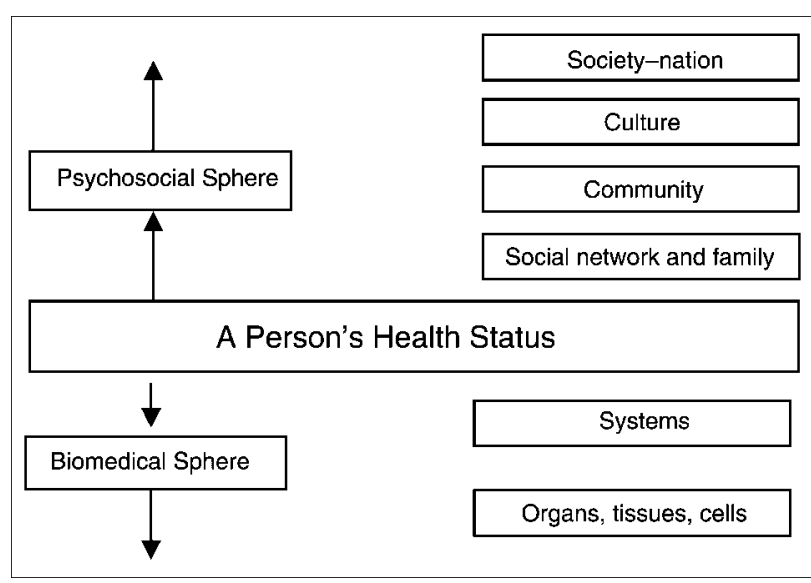

Fig. $1 \mathrm{~A}$ biopsychosocial model to demonstrate the variables that influence a person's health status. Source: Engel (1977), cited in Finau $^{33}$ settlers in the region, emphasising Western-style foods and meal patterns. A health consultant, reporting on the nutrition situation in FSM in the 1970s, wrote: 'Some of the expatriates consider, quite wrongly, the menu of the local population monotonous and of inferior quality. This attitude is particularly dangerous. ${ }^{43}$ Examples of US policies affecting dietary guidelines and promoting culturally inappropriate US-type foods have been described previously ${ }^{14}$.

Another problem noted by informants is that local foods often have low status. This is a problem throughout the Pacific $^{6,32}$. One Pacific leader was quoted as saying: 'Now people look down on local foods as inferior to imported foods. ${ }^{44}$ FSM informants said that imported foods have 'class', because they must be purchased and are related to higher incomes. Yet, if FSM local foods are purchased, they are often more expensive than imported foods (market surveys indicated that cooked rice costs US\$0.02 per $100 \mathrm{~g}$ whereas cooked banana, edible portion, costs US\$0.07 to 0.18 per $100 \mathrm{~g}$ ). This presents barriers to local food purchases.

A further barrier to FSM preventive health work is local concepts associated with health and illness, which can be very different from Western concepts. One informant said, 'We are not health-conscious like you foreigners, we eat what we like', expressing the general attitude in FSM about food choice. There are also strong beliefs in the relationship of the supernatural and spirits with health ${ }^{36,45-47}$. Advice on the nutritional benefits of a food may not be accepted by someone believing that the particular nutritional problem resulted due to disagreements and disturbing the spirits.

Harmony is particularly valued in Micronesia and other island societies ${ }^{34}$. People are said to be suspicious of individuals with new ideas ${ }^{46}$, an attitude that can present difficulties for implementing change. Church, traditional leaders and municipality groups are important forces in FSM, although there has been some breakdown of the traditional social system ${ }^{35}$. The 'mother-child connection' 
was suggested as the primary channel to utilise in developing improved health habits ${ }^{48}$.

These observations show that Micronesian values involve attitudes to food, community and health that are fundamentally different to those in Western and many other cultures, with important implications for programmes and policies. Participatory action approaches and involving communities in all phases of a nutrition improvement intervention as a broad, two-way concept has been shown to be beneficial in the problem-solving process for alleviating $\mathrm{VAD}^{49}$. This type of community approach for health care and nutrition work has been recommended for FSM, but policies and programmes have fluctuated, catering towards hospital-based, acute, medical care provision ${ }^{35,40,46}$.

\section{Food classifications}

To fully understand the implications for interventions for dietary improvement, it is important to understand the foods and how they may be classified in the perceptions of people potentially using them. Food classifications are summaries that help us to understand relationships, how order has arisen and traditional food systems ${ }^{32}$. The starchy staple foods, including breadfruit, banana, the different types of taro and yam, arrowroot, cassava and sweet potato, have been the basis of the Pacific Island diet for many years ${ }^{50}$. Legends often talk about these foods ${ }^{51}$. Early European visitors to the islands wrote descriptively about the variety of these foods and the ease with which the foods were obtained. Banks, writing in 1769, noted: 'Besides the bread-fruit the earth almost spontaneously produces cocoanuts; bananas of thirteen sorts, ...plantains, ...sweet potatoes, yams; a kind of arum...' (cited in Pollock ${ }^{32}$, p. 15). Special skills were developed in growing these foods, and these skills were often kept secret within families ${ }^{50,52}$. Calendars were developed for the sequence of planting activities, many of these being recorded by missionaries.

Foods may be classified as crops or as feast foods, foods that may be presented at ceremonies, foods to which access is restricted to certain groups, or medicine foods. In the past, certain foods were presented ceremonially in Pohnpei as first-fruits tributes to the traditional leaders, including both seasonal foods (breadfruit, yam, pandanus, mango) and non-seasonal foods (such as banana and giant swamp taro $)^{16}$. Kosrae informants described one medicine food for young children, ono en mesien talik. In many Pacific islands, the starchy foods are termed 'real foods' 32 , which describes the importance of these foods. Foods are also classified according to how they are eaten in the meal. Most people identify the starchy foods as the predominant food and the accompanying dish as that which provides satisfaction, completing what is called the meal ${ }^{32,53}$. FSM informants had terms for the main food and accompanying dish, but this varied by island and ethnic group. As starchy foods have been so important in FSM, it is likely that an intervention based on cultivars of these staple foods might be effective (Table 2).

Thus, a way of food classification such as the Three Food Groups (energy, body-building and protective foods), which is different from the traditional way, may not be acceptable within the local context. In the nondirected pile sorting, participants grouped foods closely to how they had been taught in school (according to the Three Food Groups). However, the same informants also explained that in their real meals they did not follow this approach (e.g. foods are eaten as snacks). For example, in order to encourage the consumption of raw fruits, it may be more socially acceptable to promote them as regular snack foods for both health and enjoyment. In order to encourage the consumption of dark green leafy vegetables, it is likely that these foods will be accepted if presented as something to accompany a major dish (in the fish or meat soup or other recipe), a relish rather than a dish on its own.

\section{Health care and community expertise}

The Pacific Basin Medical Officers Training Program (based in Pohnpei from 1984 to 1996) provided locally appropriate training (including nutrition training) for medical officers, guided by the biopsychosocial model ${ }^{33}$. However, there is a shortage of health and nutrition professionals in the Pacific, particularly of Pacific Island origin $^{54}$, limiting implementation of food-based culturally relevant nutrition interventions. In FSM there is a lack of nutrition expertise in all four states. There are also few

Table 2 Terms for starchy foods and accompanying dishes in different states of the Federated States of Micronesia (FSM)

\begin{tabular}{llll}
\hline FSM state & \multicolumn{1}{c}{ Area of the state } & Main dish (starchy food) & Accompanying dish (fish or meat) \\
\hline Chuuk & Main island and lagoon islands & sitas or mwongo sitas & seni \\
& Outer islands & sitas or mwongo sitas & salei \\
Kosrae & Not applicable & mongo yok staat & sali \\
Pohnpei & Madolenihm, Nett (areas of the main island) & mwenge & sali \\
& Kitti (area of the main island) & mwoangoa & sali \\
& Mokil (outer island) & mwenge & jallali \\
& Pingelap (outer island) & mwunge & giitagi \\
& Nukuoro (outer island) & gai & thimag \\
\hline
\end{tabular}

Source: data taken from field notes, Englberger (2001, 2003). 
people researching and writing about nutrition phenomena in the Pacific. Finau pointed out that a particular landmark document published in $1984^{6}$, which reviewed 450 publications on diet and health in Pacific Island populations, included only 13 papers involving Pacific Islanders as authors and only two with Pacific Islanders as first authors ${ }^{55}$. This suggests that much of the nutrition research in the Pacific often does not reflect Pacific values. Thus there is a need for both more nutritionists and more involvement of nutritionists from Pacific Island backgrounds in research.

A significant issue with implications for locally provided health care and community expertise is that a large portion of FSM health budgets (up to 25\%) are spent on off-island medical referrals, leaving little for preventive health care $^{35,46}$.

\section{Interventions for VAD alleviation}

There are several requirements characterising a local food that might be most successful in increasing carotenoid intakes and alleviating VAD in FSM. Such a food should:

1. Be high in carotenoids, especially provitamin A carotenoids (for plant foods) or retinol (for animal foods), and be eaten in small amounts or offer medium or low amounts of provitamin A carotenoids or retinol but be eaten in large amounts.

2. Have the potential to be:

- Widely consumed, especially by the target groups in the population;

- Low-cost or widely grown as part of family food production or gathered from the land or sea with no or little cost involved;

- Highly available in the markets or from family food production or acquisition;

- High-status and prestigious for growing (or acquiring) and consuming;

- Convenient in growing (or acquiring), storing, cooking and transporting;

- Convenient in readiness for consumption.

3. Have acceptability relating to:

- Agronomic factors, adapted to climate, soils, growing conditions, time required for growth and harvesting, large bunch, corm or fruit size;

- Positive organoleptic characteristics including taste, sweetness, smell, juiciness, texture, softness, stickiness (desirable in taro), ability to fill and satisfy;

- Food preparation and consumption factors including length of cooking time, adaptability for a variety of recipes.

There are two target groups, children and adults. Adults can be divided into subgroups. First, there are those with normal and those with limited chewing ability. Of the four local staple foods, ripe banana is particularly suitable for children, due to its sweetness and softness, and for people with chewing limitations. Giant swamp taro, with its hard texture, is better suited for adults with good teeth, but it can be ground and cooked for children and those with compromised chewing. Only those who can chew can consume raw unprocessed pandanus. Another adult subgroup includes pregnant and lactating women, who have additional nutritional requirements. In respect to VAD, the poor VA status in FSM children is not always accompanied by a high prevalence of other malnutrition indicators $2,56,57$. Intakes of energy, protein and fat appear to be adequate among Kosrae children ${ }^{22}$. Thus, an intervention focusing on VA- and carotenoid-rich foods, rather than a more diffuse programme, may be more effective.

In terms of the adult target group, one possible approach would be to integrate the promotion of carotenoid-rich foods for controlling chronic diseases with the promotion of those foods to control VAD. Informants pointed out that community people are asking what to eat to avoid chronic diseases, whereas they are not asking what to eat to avoid VAD. Thus, a programme that includes attention to health benefits for both VAD and chronic diseases is more likely to be 'heard' by the people because chronic disease prevention is a 'felt need'.

Consideration should be made on whether the focus is on one food ${ }^{49}$ or a broader approach promoting a range of foods. As agronomic conditions vary in FSM, a single food approach is less likely to be effective. Possibly the most effective approach would be one overall message: the increased consumption of yellow staple foods (yellow coloration roughly indicating carotenoid content ${ }^{21}$ ). For each island group the programme could target its specific plant cultivars or animal foods.

\section{Implications for general dietary improvement from plant sources}

A general dietary improvement can be achieved by the increased consumption of micronutrient-rich plant foods. Although the case here refers to increasing the intake of VA for alleviating VAD, this same approach can be applied to increase the consumption of other nutrients available in plant foods. The staple FSM plant foods offer the most potential as foods to promote, as they are eaten most often. However, it is necessary to consider which cultivars might best be promoted. After analysing data relating to carotenoid content, food cultivar characteristics, acceptability and the place of these foods in the diet, some local foods have greater potential for dietary improvement, although there would necessarily have to be some differences based on the specific context (e.g. range of foods grown on each island, varying agronomic conditions and acceptability). As banana appears to meet more of the requirements than the other foods, promotion of context-appropriate banana cultivars may be more likely to improve VA status, compared with other foods (Table 3). 
Table 3 Comparison of plant staple foods in the Federated States of Micronesia for fulfilling requirements to potentially contribute meaningfully to vitamin $A(V A)$ status

\begin{tabular}{|c|c|c|c|c|}
\hline Requirement & Banana & Giant swamp taro & Breadfruit & Pandanus \\
\hline $\begin{array}{l}\text { Several VA-rich } \\
\text { cultivars* }\end{array}$ & $\begin{array}{l}\text { Yes - but many } \\
\text { are rare }\end{array}$ & Yes - but many rare & No - only one cultivar & $\begin{array}{l}\text { Yes - but only } \\
\text { a few analysed }\end{array}$ \\
\hline Widely consumed & $\begin{array}{l}\text { Yes - but many } \\
\text { are rare }\end{array}$ & $\begin{array}{l}\text { Yes - but many rare, } \\
\text { less eaten by children }\end{array}$ & Yes - on some islands & $\begin{array}{l}\text { Yes - on some islands, } \\
\text { but eaten as a snack }\end{array}$ \\
\hline Low-cost & $\begin{array}{l}\text { No - compared } \\
\text { with rice }\end{array}$ & $\begin{array}{l}\text { No - not marketed } \\
\text { in Kosrae }\end{array}$ & No - not marketed & $\begin{array}{l}\text { No - costly compared with } \\
\text { other snack foods }\end{array}$ \\
\hline $\begin{array}{l}\text { Highly available: } \\
\text { as marketed }\end{array}$ & $\begin{array}{l}\text { No - only two } \\
\text { are marketed }\end{array}$ & No & No & No \\
\hline $\begin{array}{l}\text { Highly available: } \\
\text { as home grown }\end{array}$ & $\begin{array}{l}\text { Yes - some } \\
\text { (Taiwang) }\end{array}$ & Yes & Yes - on some islands & Yes - on some islands \\
\hline High-status & $\begin{array}{l}\text { Yes - some, } \\
\text { but not Taiwang }\end{array}$ & No & Yes - on some islands & No \\
\hline Convenience: growing & Yes & No & No & Yes \\
\hline $\begin{array}{l}\text { Convenience: } \\
\text { storing/transporting }\end{array}$ & No & $\begin{array}{l}\text { No - but can stay in the } \\
\text { soil for many years }\end{array}$ & No & No \\
\hline Convenience: ready-to-eat & Yes & No & Yes & Yes \\
\hline $\begin{array}{l}\text { Acceptability: } \\
\text { organoleptic factors }\end{array}$ & Yes & $\begin{array}{l}\text { Yes - some cultivars and } \\
\text { if prepared well }\end{array}$ & Yes & Yes \\
\hline $\begin{array}{l}\text { Acceptability: } \\
\text { agronomic factors }\end{array}$ & $\begin{array}{l}\text { Yes - for some } \\
\text { (Taiwang), but not } \\
\text { for many }\end{array}$ & $\begin{array}{l}\text { Yes - but a swampy } \\
\text { area is needed }\end{array}$ & $\begin{array}{l}\text { Yes - on atolls but less } \\
\text { so on other islands }\end{array}$ & Yes - on coastal areas \\
\hline $\begin{array}{l}\text { Acceptability: } \\
\text { cooking factors }\end{array}$ & Yes & No - long cooking time & Yes & $\begin{array}{l}\text { Cooked on only } \\
\text { a few islands }\end{array}$ \\
\hline Overall score† & 9 & 5 & 7 & 7 \\
\hline
\end{tabular}

Note: these data refer to the staple food as a group. The food cultivars per staple food also display differences for these requirements and could each be evaluated separately in a similar manner.

${ }^{*}$ Refers mainly to Kosrae and Pohnpei cultivars.

† Score from counting number of requirements fulfilled.

There are differences among the four foods and food cultivars focused on in this study and how they meet the requirements for a food that may be effectively promoted (Table 3). For example, giant swamp taro requires a long cooking time, some cultivars requiring $3 \mathrm{~h}$, which is a distinct disadvantage in terms of time and fuel. There are differences as to which cultivars are used for feasts, which are an important part of Pacific life. Both foods and food cultivars should be evaluated to consider whether they could be effectively promoted in a locality. Consideration also must be given to the relationship of cooking, social involvement and women's roles, which are changing along with lifestyle changes.

Food cultivars can be grouped several ways. They may be grouped as foods that presently have good acceptability and, thus, are likely to be easily promoted but which may be limited by factors such as inadequate quantities of planting material. This includes a number of high-carotenoid banana cultivars that are now rare, such as Pohnpei Karat (Usr Kulasr in Kosrae, Arai in Yap, and Danan in Chuuk). To promote this food consideration would need to be given to community recognition and cultural beliefs and agriculture. In the past most agricultural development efforts were concentrated on export production crops, such as pepper, with little efforts on promotion of family food production $\operatorname{crops}^{16}$. However, attitudes are changing. One FSM agriculture leader said: 'It is important that we promote our VA-rich bananas.'
In Pohnpei, Karat has been the traditional weaning food and is believed to have special health benefits. A oneyear programme was carried out in Pohnpei in 1999 for promoting Karat, which had been the traditional weaning food, but had become rare due to neglect. The programme resulted in a great increase in production of Karat, despite the short programme length and minimal funding, and since that time Karat has been marketed in Pohnpei, although it had not been marketed previous to the campaign, showing the impact of the intervention ${ }^{58}$. Many Kosrae and Chuuk informants were no longer familiar with this banana. In Chuuk the cultivar apparently died out. Yap informants said that Arai is considered a lowcaste food (for outer islanders) and, thus, a fine-tuned approach would be needed for promoting this food throughout FSM.

On the other hand, one banana cultivar (Taiwang) was readily available and well-liked for its taste and for certain recipes, but had low status, mainly due to its ready availability, ease in growing and association as a poor man's food'. Some informants maintained that its status could be raised if it were promoted as a nutrient-rich food.

The convenience of imported foods is an important factor. Informants described new innovations that could greatly increase local food preparation convenience, including electric machines for grinding taro, but these are still not widely available. New breadfruit preservation methods use plastic containers but need further development. Improved marketing strategies for local foods need 
development and could increase convenience and availability of these foods. Marketing is another area that has been neglected.

Attitudes on selling and purchasing local foods may need to change. Informants explained that on some islands people believe that trees (breadfruit) would no longer produce well if crops were sold, rather than freely shared. Some informants explained that they feel ashamed to purchase local foods. In this transition period from subsistence to a market economy, people still feel that they should be producing their own food. Yet, with salaried employment, there is less time available for some people to grow their own food and increasing use may result from local community sale or exchange.

\section{Implications for dietary improvement from animal sources}

Animal products considered the best sources of VA (milk, dairy products, eggs, liver) may be prohibitive because of their cost ${ }^{9,59}$. Furthermore, although milk and eggs may contribute importantly to VA intake ${ }^{60,61}$, they are imported foods in FSM, being relatively expensive and less commonly eaten ${ }^{22}$. Protein intake in FSM is already high $^{22}$. Thus, the aim of promoting FSM protein foods for improving VA status should be a shift from consuming protein foods low in VA content (i.e. imported chicken and turkey tail*) to greater consumption of protein foods higher in VA content, including fish liver and seafood.

\section{Implications for promoting fortified foods}

Food fortification is an appropriate intervention for VAD in some developing countries ${ }^{62}$. However, in the context of FSM in particular, this recommendation should be carefully examined. Rice, sugar and wheat flour are the major staples. However, FSM people have specific taste preferences for rice. Fortified rice provided by US food aid to FSM was disliked; people often gave it to the pigs or washed off the fortified coating (Snowdon W, personal communication, 2002). FSM has no industrialised food processing. A food fortification programme would necessitate importing foods that are already fortified, which would be likely to have high costs.

\section{Conclusions}

A systematic consideration of factors relating to a foodbased intervention may be critical to its success. As there are many differences between Pacific or Micronesian and Western values, these need to be understood and considered as they may counteract the message for improving health. This includes the concept of food (social aspects vs. physical biological aspects) and local food classifications. Considering the predisposing,

*Turkey tails are literally the tails of the turkeys. enabling and reinforcing factors relating to an intervention may provide a strategic approach to its planning ${ }^{29}$. As more FSM people recognise chronic disease problems (diabetes, heart disease and cancer) than VAD, an intervention promoting foods and nutrients important for protecting against both chronic disease and VAD may have a greater impact than promoting foods simply for protection against VAD.

There are basic differences in FSM staple foods and cultivars by nutrient content, consumption level, cost, availability, status, convenience in growing, storing, transporting, cooking and ready-to-eat aspects, and organoleptic factors - all contributing to acceptability. A systematic review of banana, giant swamp taro, breadfruit and pandanus indicates that a food-based intervention based on these foods could be successful, but that the potential varies according to island and ethnic group, and that selection of the food cultivar is important. This paper, and the concept of systematically reviewing each food and food cultivar for its potential in a promotion, may be relevant to other islands of FSM and the Pacific as well as other areas where similar foods are grown and where food-based interventions are being planned, particularly in relation to VAD and chronic disease prevention. Finally, the data presented here indicate that an ethnographic approach was essential in understanding the cultural context and for the data collection and analysis upon which these recommendations were made.

\section{Acknowledgements}

The University of Queensland provided an International Postgraduate Research Scholarship for L.E., who collected some of the data as part of her $\mathrm{PhD}$ research project. The Task Force Sight and Life, Thrasher Research Fund and the US Centers for Disease Control and Prevention provided funds to support the research. We especially acknowledge all those informants who helped provide an understanding of Micronesian and Pacific values and other factors that are important for carrying out food-based interventions in FSM and the Pacific, including a special acknowledgement to Dr Eliuel Pretrick, Adelino Lorens, Nena Nena, Dr Hiroshi Ismail, Jane Elymore, Bill Raynor, Julie Timothy, Procula Jackson and Mele'ofa Malolo.

\section{References}

1 Auerbach S. Report of Pohnpei Child Health Survey. Findings presented to the Federated States of Micronesia and Pohnpei State Department of Health Services. Palikir, Pohnpei: US Public Health Service and FSM Department of Health Service, 1994

2 Centers for Disease Control and Prevention. Vitamin A deficiency among children - Federated States of Micronesia, 2000. MMWR Morbidity and Mortality Weekly Report 2001; 50(24): 509-12.

3 Lloyd-Puryear M, Humphrey JH, West KP, Aniol K, Mahoney J, Keenum DG. Vitamin A deficiency and anemia 
among Micronesian children. Nutrition Research 1989; 9 1007-16.

4 Lloyd-Puryear M, Mahoney J, Humphrey JH, Mahoney F, Siren N, Moorman C, et al. Xerophthalmia, vitamin A deficiency in Micronesia: a state-wide survey in Chuuk. Nutrition Research 1991; 11: 1101-10.

5 Auerbach S. Obesity, Hypertension, and Type II Diabetes Mellitus and the Non-communicable Diseases (NCD) Program in the Federated States of Micronesia. Report of activities carried out for the PHHS MINIGRANT \& related activities. Pohnpei: FSM Department of Health, 1999.

6 Coyne T, Badcock J, Taylor R. The Effect of Urbanisation and Western Diet on the Health of Pacific Island Populations. SPC Technical Paper No. 186. Noumea, New Caledonia: South Pacific Commission, 1984

7 Coyne T. Lifestyle Diseases in Pacific Communities. Noumea, New Caledonia: Secretariat of the Pacific Community, 2000

8 Shmulewitz D, Auerbach SB, Lehner T, Blundell ML, Winick JD, Youngman LD, et al. Epidemiology and factor analysis of obesity, type II diabetes, hypertension, and dyslipidemia (syndrome $\mathrm{X}$ ) on the island of Kosrae, Federated States of Micronesia. Human Heredity 2001; 51 8-19.

9 McLaren DS, Frigg M. Sight and Life Manual on Vitamin A Deficiency Disorders (VADD), 2nd ed. Basel, Switzerland Task Force Sight and Life, 2001.

10 Bertram JS. Lectures presented at the 13th International Symposium on Carotenoids held in Honolulu, Hawaii, USA 6-11 January 2002. Pure and Applied Chemistry 2002; 74(8): 1369-478.

11 Ford ES, Will JC, Bowman BA, Narayan KM. Diabetes mellitus and serum carotenoids: findings from the Third National Health and Nutrition Examination Survey. American Journal of Epidemiology 1999; 149: 168-76.

12 Mares-Perlman JA, Millen AE, Ficek TL, Hankinson SE. The body of evidence to support a protective role for lutein and zeaxanthin in delaying chronic disease. Overview. Journal of Nutrition 2002; 132(3): 518S-24S.

13 World Cancer Research Fund. Food, Nutrition and the Prevention of Cancer: A Global Perspective. Washington, DC: American Institute for Cancer Research, 1997.

14 Englberger L, Marks GC, Fitzgerald MH. Insights on food and nutrition in the Federated States of Micronesia: a review of the literature. Public Health Nutrition 2003; 6(1): 5-17.

15 Hezel FX. The New Shape of Old Island Cultures: A Half Century of Social Change in Micronesia. Honolulu, HI: University of Hawaii Press, 2001.

16 Raynor B. Agroforestry Systems in Pohnpei - Practices and Strategies for Development. Pohnpei, Federated States of Micronesia. RAS/86/036 Field Document 4. FAO/UNDP South Pacific Forestry Development Programme, 1991.

17 Rody N. Consumerism in Micronesia. South Pacific Bulletin 1978; 28: 9-14.

18 Englberger L, Aalbersberg W, Fitzgerald MH, Marks GC, Chand K. Provitamin A carotenoid content and cultivar differences in edible pandanus fruit Pandanus tectorius Journal of Food Composition and Analysis 2003; 16(2): 237-47.

19 Englberger L, Aalbersberg W, Ravi P, Bonnin E, Marks GC, Fitzgerald $\mathrm{MH}$, et al. Further analyses on Micronesian banana, taro, breadfruit and other foods for provitamin A carotenoids and minerals. Journal of Food Composition and Analysis 2003; 16(2): 219-36.

20 Englberger L, Schierle J, Marks GC, Fitzgerald MH Micronesian banana, taro, and other foods: newly recognized sources of provitamin A and other carotenoids. Journal of Food Composition and Analysis 2003; 16(1) $3-19$.

21 Rodriguez-Amaya DB. A Guide to Carotenoid Analysis in Foods. Washington, DC: ILSI Press, 1999.
22 Englberger L. A community and laboratory-based assessment of the natural food sources of vitamin $A$ in the Federated States of Micronesia. PhD thesis, University of Queensland, Brisbane, Australia, 2003.

23 Kuhnlein HV, Pelto GH, eds. Culture, Environment, and Food to Prevent Vitamin A Deficiency. Boston, MA: International Nutrition Foundation for Developing Countries, 1997.

24 Blum L, Pelto PJ, Pelto GH, Kuhnlein HV. Community Assessment of Natural Food Sources of Vitamin A: Guidelines for an Ethnographic Protocol. Ottawa: International Development Research Centre, 1997.

25 Fitzgerald MH. Ethnography. In: Higgs J, ed. Qualitative Research: Discourse on Methodologies. Sydney: Hampden Press, 1997; 48-60.

26 Miles MB, Huberman AM. Qualitative Data Analysis, 2nd ed. Thousand Oaks, CA: Sage Publications, 1994.

27 Booth SL, Sallis JF, Ritenbaugh C, Hill JO, Birch LL, Frank LD, et al. Environmental and societal factors affect food choice and physical activity: rationale, influences, and leverage points. Nutrition Reviews 2001; 59(3): S21-39.

28 Economos CD, Brownson RC, DeAngelis MA, Novelli P, Foerster SB, Foreman CT, et al. What lessons have been learned from other attempts to guide social change? Nutrition Reviews 2001; 59(3): S40-56.

29 Green LW, Kreuter MW. Health Promotion Planning: An Educational and Environmental Approach, 2nd ed. Mountain View, CA: Mayfield Publishing Company, 1991.

30 Iannotti L, Gillespie S. Successful Community Nutrition Programming: Lessons from Kenya, Tanzania, and Uganda. Washington, DC: United States Agency for International Development/Academy for Educational Development, 2002.

31 Schultz J. Nutrition education in the Pacific. Present status of noncommunicable disease in the Pacific: what next? In: Proceedings of SPC Regional Nutritionists Workshop, Auckland, New Zealand, 18-20 September 1999. Noumea, New Caledonia: Secretariat of the Pacific Community, 1999; 56-60.

32 Pollock NJ. These Roots Remain: Food Habits in Islands of the Central and Eastern Pacific since Western Contact. Laie, HI: The Institute for Polynesian Studies, 1992.

33 Finau SA. Health care in the Pacific: who would bell the cat? Pacific Health Dialog 1994; 1(1): 44-55.

34 Rody N. Empowerment as organizational policy in nutrition intervention programs: a case study from the Pacific Islands. Journal of Nutrition Education 1988; 20(3): 133-41.

35 Federated States of Micronesia. A Situation Analysis of Children and Women in the Federated States of Micronesia. Suva, Fiji: UNICEF Pacific, 1996.

36 Fitzgerald MH. Whisper of the Mother: From Menarche to Menopause among Women in Pohnpei. Westport, CT: Greenwood Publishing Group, Inc., 2001.

37 Debunce LA. Cultural changes in horticultural practices on the high island of Kosrae, Micronesia. PhD thesis, University of Oregon, Eugene, OR, 1996.

38 Lewis JL. Kusaiean Acculturation 1824-1948. Division of Land Management, Trust Territory of the Pacific Islands, reprint ed. Saipan, Mariana Islands: Pacific Science Board of the National Research Council, Coordinated Investigation of Micronesian Anthropology, 1967.

39 South Pacific Commission. Rethinking Food Guidance in the Pacific: Workshop Report. Noumea, New Caledonia: South Pacific Commission, 1996.

40 Barker C. Review of the Family Food Production and Nutrition Project. Report prepared for the UNICEF Pacific Programme Office, Suva, Fiji, 21 July-30 September 1995. Suva, Fiji: UNICEF Pacific, 1996.

41 Schoeffel P, Bolabola C, Ngirmidol C. The UNICEF Family Food Production and Nutrition Project. Evaluation Report. 
Christchurch, New Zealand: DSIR Social Science, Ilam Research Centre, 1991.

42 Thaman RR. Foods and drinks for the 21st century in Fiji. Fiji Food and Nutrition Newsletter 1999; 24(4): 1-3.

43 Jansen AAJ. Report on a Field Visit to the Trust Territory of the Pacific Islands 16 February-2 March 1972. WPRO 5601 (TTPI). Manila: WHO Regional Office for the Western Pacific, 1972

44 Crocombe R. The South Pacific. Suva, Fiji: University of the South Pacific, 2001.

45 Demory BGH. An illusion of surplus: the effect of status rivalry upon family consumption. $\mathrm{PhD}$ thesis, University of California, Berkeley, CA, 1976.

46 Flear J. Good intentions: good enough? Observations of the sociocultural aspects of health care delivery in Micronesia. Presented at the Institutes of Medicine Meeting, 18-19 April 1997. Saipan: Commonwealth of the Northern Mariana Islands, 1997.

47 Ward RL. Curing on Ponape: a medical ethnography. PhD thesis, Tulane University, New Orleans, LA, 1977.

48 Pretrick E. Guest editorial. Pacific Health Dialog 1994; 1(1): $4-5$.

49 Smitasiri S, Attig GA, Dhanamitta S. Participatory action for nutrition education: social marketing vitamin A-rich foods in Thailand. Ecology of Food and Nutrition 1992; 28: 199-210.

50 Malolo M, Matenga-Smith T, Hughes R. The Staples We Eat. Noumea, New Caledonia: Secretariat of the Pacific Community, 1999.

51 Tilfas R, Tolenoa A. Legends of Kosrae. Tofol, Kosrae: Curriculum Division, Kosrae Education Department, Kosrae State Government, 1993.

52 Raynor B, Lorens A, Phillip J. Traditional yam cultivation on Pohnpei, Eastern Caroline Islands, Micronesia. Economic Botany 1992; 46(1): 25-33.
53 Bascom WR. A Pacific Economy in Transition. Volume 22. Berkeley, CA: University of California Press, 1965.

54 Malolo M. Nutrition training: needs and priorities in the Pacific. Pacific Health Dialog 1997; 4(1): 166-71.

55 Finau SA, Finau E, 'Ofanoa M. Research imperialism in Pacific health: the case of Tonga (1966-1977). Pacific Health Dialog 2000; 7(2): 109-14.

56 Elymore J, Elymore A, Badcock J, Bach F, Terrell-Perica S. The 1987/88 National Nutrition Survey of the Federated States of Micronesia. Technical report prepared for the Government and Department of Human Resources of the FSM. Noumea, New Caledonia: South Pacific Commission, 1989.

57 Van der Haar F. Vitamin A deficiency in Micronesia. Sight and Life Newsletter 2002; 3: 67-8.

58 Englberger L. Promotion of vitamin A-rich foods in Pohnpei, Federated States of Micronesia: was the 1999 campaign a success? Sight and Life Newsletter 2002; 2: 28-32.

59 Booth SL, Johns T, Kuhnlein HV. Natural food sources of vitamin A and provitamin A. Food and Nutrition Bulletin 1992; 14(1): 6-19.

60 De Pee S, Bloem MW, Satoto, Yip R, Sukaton A, Tjiong R, et al. Impact of a social marketing campaign promoting dark-green leafy vegetables and eggs in central Java, Indonesia. International Journal for Vitamin and Nutrition Research 1998; 68(6): 389-98.

61 Persson V, Greiner T, Bhagwat IP, Gebre-Medhin M. The Helen Keller International food frequency method may underestimate vitamin A intake where milk is a normal part of the young child diet. Ecology of Food and Nutrition 1999; 38: $57-69$.

62 Underwood B. Dietary approaches to the control of vitamin A deficiency: an introduction and overview. Food and Nutrition Bulletin 2000; 21(2): 117-23. 